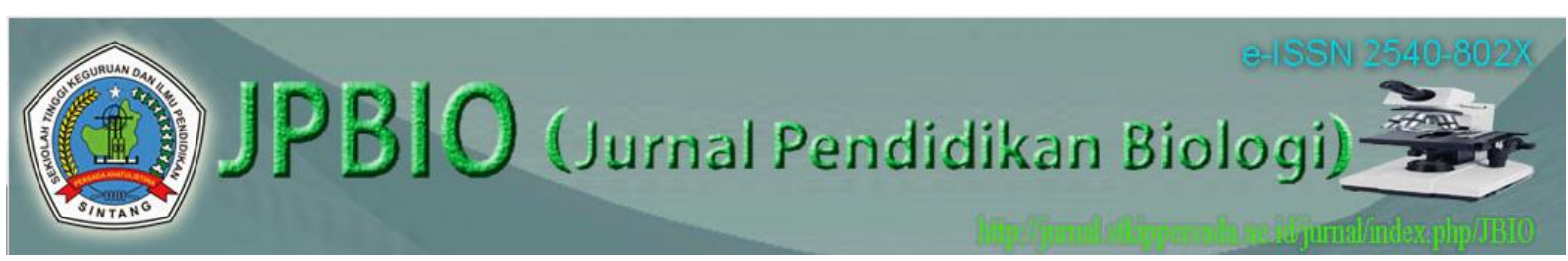

JPBIO (Jurnal Pendidikan Biologi)

Vol. 3 No. 1 April 2018 | 1 - 8

ISSN 2540-802x (Online)

DOI: http://dx.doi.org/10.31932/ JPBIO (Jurnal Pendidikan Biologi)

http://jurnal.stkippersada.ac.id/jurnal/index.php/JBIO

\title{
PENGARUH MODEL READING QUESTIONING ANSWERING TERHADAP KEMAMPUAN BERPIKIR KRITIS SISWA PADA POKOK BAHASAN SISTEM PERNAPASAN MANUSIA
}

\author{
Sudin ${ }^{1}$, Hilarius Jago Duda ${ }^{2}$, Markus lyus Supiandi ${ }^{3}$ \\ ${ }^{1}$ Mahasiswa Program Studi Pendidikan Biologi, STKIP Persada Khatulistiwa, Sintang \\ ${ }^{2,3}$ Dosen Program Studi Pendidikan Biologi, STKIP Persada Khatulistiwa, Sintang \\ E-mail: sudin.aldiyansyah@gmail.com ${ }^{1}$, hilariusjagoduda@gmail.com²* \\ msupiandi@gmail.com ${ }^{3}$
}

Diterima: 11 Januari 2018

Direvisi: 05 Februari 2018 Disetujui: 10 Maret 2018

\begin{abstract}
ABSTRAK
Penelitian ini dilatar belakangi oleh kurangnya minat baca siswa yang berpengaruh terhadap keaktifan belajar dikelas dalam meningkatkan kemampuan berpikir kritis. Tujuan penelitian ini adalah untuk mengetahui pengaruh model Reading Questioning Answering (RQA) terhadap kemampuan berpikir kritis siswa pada materi sistem pernapasan manusia. Metode yang digunakan adalah eksperimen, berbentukTru Eksperimental,dengan desain PretestPosttest Control Group Desigen. Populasi sebanyak 342 siswa dan sampel sebanyak 65 siswa yang terdiri dari kelas Eksperimen dan kelas Kontrol. Teknik pengambilan sampel menggunakan teknik Simple Random Sampling. Alat pengumpulan data menggunakan lembar observasi, soal tes, dan angket.Hasil uji hipotesis data pretest diperoleh nilai $Z_{\text {hitung }}<$ $Z_{\text {tabel }}(-0,55<1,96)$ maka $\mathrm{H}_{0}$ diterima, sedangkan data posttest diperoleh nilai $Z_{\text {hitung }}>$ $Z_{\text {tabel }}(5,76>1,96)$ maka Ha diterima. Disimpulkan bahwa model Reading Questioning Answering (RQA) berpengaruh terhadap kemampuan berpikir kritits siswa pada materi sistem pernapasan manusia di kelas VIII SMP Negeri 02 Sintang.
\end{abstract}

Kata kunci: reading questioning answering, berpikir kritis, sistem pernapasan manusia

\section{ABSTRACT}

This research is based on the lack of reading interest of students who have an effect on learning activeness in class in improving critical thinking ability. The purpose of this research is to know the influence of Reading Questioning Answering (RQA) model on students' critical thinking ability on human respiration system. The method used is experimental, form Tru Eksperimental Desigen, with Pretest-Posttest Control Group Desigen design. A population of 342 students and a sample of 65 students consisting of experimental class and control class. Sampling technique using Simple Random Sampling. The data collection tool uses observation sheets, test questions, and questionnaires. Hypothesis test analysis of pretest data obtained value of $Z_{\text {quantification }}<Z_{\text {table }}(-0,55<1,96)$ then $H_{0}$ accepted, while posttest data obtained value of $Z_{\text {quantification }}>Z_{\text {table }}(5,76>1,96)$ hence $H_{a}$ accepted. It was concluded that 
Reading Questioning Answering (RQA) learning model had an effect on students' thinking ability on the human respiration system in grade VIII SMP Negeri 02 Sintang.

Keywords: reading questioning answering, critical thinking, human respiration, syatem

\section{PENDAHULUAN}

Belajar bukan hanya sekedar menghafal tetapi belajar merupakan sebuah proses pemberdayaan pikiran terhadap fenomena atau permasalahan-permasalahan yang sedang terjadi. Untuk memahami permasalahan yang terjadi seharusnya siswa lebih terampil dalam mengelola kegiatan belajarnya.

Kegiatan tersebut tidak luput dari adanya kegiatan membaca dan memahami isi bacaan. Kegiatan membaca merupakan hal penting dalam proses belajar. Membaca merupakan proses memahami informasi dari bahan bacaan yang berupa buku, teks naskah, mading, majalah, koran dan sebagainya.

Meurut Tariga (2015: 7) "Membaca merupaka suatu proses yang dilakukan serta dipengaruhi oleh pembaca untuk memperoleh pesan yang hendak disampaikan oleh penulis melalui media kata/bahasa tulis". Kegiatan belajar berpengaruh terhadap kemampuan berpikir. Kemampuan berpikir menuntut siswa aktif dalam proses belajar. Mulyadi (2013) mendefinisikan kemampuan berpikir adalah "Penggunaan keahlian atau strategi kognitif yang meningkatkan kemungkinan mendapatkan hasil yang diharapkan".Semakin banyak pengetahuan yang diperoleh maka kemampuan emosional yangberupa keterampilan juga semakin baik, maka yang menjadi permasalahan adalah seberapa banyak pengalaman belajar atau pengetahuan baru yang diperoleh dari seorang guru untuk mengolah pikiran sehingga mampu berpikir secara kritis dan penuh rasa tanggung jawab dalam menyelesaikan permasalahan yang mereka hadapi.

Untuk dapat berpikir secara kritis ada enam indikator kemampuan berpikir kritis yang perlu dicermati diantaranya adalah "1) Merumuskan masalah; 2) Memberikan argumen; 3) Melakukan deduksi; 4) Melakukan induksi; 5) Melakukan evaluasi; dan 6) Memutuskan dan melaksanakan (Bustami, 2017)".Berpikir kritis diperlukan dalam rangka memecahkan masalah sehingga diperoleh hasil pemecahan yang tepat dan akurat.

Berdasarkan hasil pra observasi yang dilaksanakan pada SMP Negeri 02 Sintang diperoleh bahwa kemampuan berpikir siswa masih sangat rendah, terlebih pada mata

pelajaran biologi. Hal ini terlihat pada saat guru memulai kegiatan pendahuluan siswa cendrung bersifat fasif, ketika guru mencoba mengali pengertahuan awalsiswa dengan memberikan pertanyaan terkait materi yang akan disampaikan hanya sedikit dari mereka yang memberikan jawabannya. Siswa jarang membaca buku, jarang menulis, bahkan menjawab pertanyaan. Diakhir pembelajaran guru mengevaluasi siswa dengan merangkum materi pelajaran. Dari evaluasi tersebut terlihat hanya sedikit siswa yang memberikan evaluasinya.

Melihat realita tersebut maka seharusnya guru lebih terampil dalam menggunakan model dan metode yang tepat agar tercipta suasana belajar yang nyaman aktif, kreatif dan penuh rasa tanggung jawab. Adapun model satu-satunya yang dapat digunakan adalah model Reading Questioning Answering (RQA). Model ini dimulai dari Reading (membaca), kemudian Questioning (bertanya atau membuat pertanyaan), dan Answering (menjawab atau membuat jawaban dari pertanyaan).

Kombinasi ketiga proses tersebut sangat baik digunakan guru dalam menghadapi siswa yang bersifat pasif. Implementasi Model Reading, Questioning Answering (RQA) terbukti mampu memaksa para siswa untuk membaca materi yang ditugaskan, sehingga model pembelajaran yang dirancang dapat terlaksana dan pemahaman terhadap materi pembelajaran berhasil ditingkatkan hampir 100\% (Corebima, 2009).

Strategi $R Q A$ memaksa siswa membaca dan memahami isi bacaan, berupaya menemukan isi bacaan yang substansial atau sangat substansial, membuat pertanyaan, serta menjawab pertanyaan yang dibuatnya, lebih cenderung pada penguatan kognitif peserta didik (Bahtiar, 2013). Melalui kegiatan membaca, membuat pertanyaan, dan 
menjawab pertanyaan akan menciptakan keaktifan belajar siswa sehingga siswa benarbenar ditugasi belajar dan akan meningkatkan kemampuan berpikir kritis (Bustami \& Corebima 2017). Menurut Fisher (2008: 10) "Berpikir kritis merupakan interprestasi dan evaluasi yang termapil dan aktif terhadap observasi dan komunikasi, informasi dan argumentasi".

Kemampuan berpikir kritis dapat diwujudkan melalui pemahaman terhadap konsep pembelajaran, pemberdayaan pikiran yang menuntut siswa aktif dan benar-benar belajar. Dengan demikian tanggung jawab yang diberikan tentunya dapat menciptakan sebuah pemahaman yang mendalam terhadap topik khusus, sehingga kemampuan dalam menalar, memberikan argumen, mengevaluasi, dan merumuskan masalah terhadap topik pembahasan dapat diwujudkan melalui model Reading Questioning Answering (RQA).

Berdasarkan uraian diatas, peneliti tertarik mengambil judul penelitian, yaitu "Pengaruh model Reading Questioning Answering (RQA) terhadap kemampuan berpikir kritis siswa kelas VIII SMP Negeri 02 Sintang pada pokok bahasan sistem pernapasan manusia". Peneliti merasa lebih efektif dan efisien jika model yang digunakan tersebut mampu meningkatkan kemampuan berpikir kritis siswa di SMP Negeri 02 sintang.

\section{METODE PENELITIAN}

Pendekatan penelitian ini menggunakan Pendekatan Kuantitatif, metode Eksperimen dengan Bentuk Quasi Eksperimental, desain menggunakan Pretest-Posttest Control Group Desigen. Rancangan desain ini dapat dilihat pada Table1.

Tabel 1. Pretest-Posttest Control Group Desigen

\begin{tabular}{llll}
\hline Group & Pretest & Treatment & Posttest \\
\hline Eksperimen & $\mathrm{O}_{1}$ & $\mathrm{X}$ & $\mathrm{O}_{2}$ \\
\hline Control & $\mathrm{O}_{3}$ & - & $\mathrm{O}_{4}$ \\
\hline & & & Sumber: Sugiyono (2011: 76
\end{tabular}

\section{Keterangan:}

$\mathrm{X} \quad=$ adanya perlakuan Reading Questioning Answering(RQA)

- $\quad$ = tidak ada perlakuan

$\mathrm{O}_{1}=$ pretest kelas eksperimen

$\mathrm{O}_{2} \quad=$ posttestkelas eksperimen

$\mathrm{O}_{3}=$ pretest kelas kontrol

$\mathrm{O}_{4} \quad=$ posttest kelas kontrol

Populasi dalam penelitian ini berjumlah 342 siswa sedangkan sampel berjumlah 65 siswa yang terdiri dari 33 siswa kelas eksperimen dan 32 siswa kelas kontrol. Kelas eksperimen diberi perlakuan (treatment) menggunakan model Reading Questioning Answering (RQA) sedangkan kelas kontrol tidak diberi perlakuan atau menggunakan metode konvensional. Pengambilan sampel menggunakan teknik "Simple Radom Sampling". Menurut Sugiyono (2013: 120) Teknik Simple Random Sampling adalah "Pengambilan anggota sampel dari populasi dilakukan secara acak tampa memperhatikan stara yang ada dalam populasi itu".

Teknik pengumpulan datamenggunakan 1) teknik observasi langsung, 2) teknik pengukuran, 3) teknik komunikasi tidak langsung.Alat pengumpulan data menggunakan 1) lembar observasi, 2) soal tes, 3) Angket. Teknik analisis data menggunakan 1) analisis hasil observasi, 2) teknik analisis hasil tes yang terdiri dari a) uji normalitas, b) uji homogenitas, dan c) uji hipotesis, menggunakan ji $Z$ dua sampel, 3) teknik analisis angket.

\section{HASIL DAN PEMBAHASAN PENELITIAN}

Observasi guru kelas eksperimen dan kontrol diobservasi oleh guru mata pelajaran SMP Negeri 02 Sintang.Berdasarkan analisis observasi guru kelas eksperimen pada 
pertemuan pertama dan pertemuan kedua, didapat hasil prsentase degan rata-rata $100 \%$, sehingga berkriteria "sangat baik".

Artinya dari kedua pertemuan tersebut guru telah melaksanakan pembelajaran mulai awal hingga akhir proses pembelajaran, sesuai dengan rangkaian kegiatan pembelajaran yang terdapat pada Rencana Pelaksanaan Pembelajaran dengan menerapkanmodel Reading Questioning Answering (RQA).

Analisis data observasi guru kelas kontrol pada pertemuan pertama dan keduadidapat hasil presentase dengan rata-rata nilai sebesar $100 \%$ dengan kriteria "sangat baik". Artinya guru telah melaksanakan pembelajaran mulai dari awal sampai selesainya kegiatan pembelajaran sesuai dengan rangkaian kegiatan pembelajaran yang terdapat pada Rencana Pelaksanaan Pembelajaran dengan mengunakan metode konvensional.

Berdasarkan penerapan model dan metode tersebut terhadap aktivitas dan peran guru menunjukan bahwa penggunaan model Reading Questioning Answering (RQA) memudahkan guru dalam memfasilitasi dan membimbing kegiatan siswa selama kegiatan belajar berlangsung.

Menurut Corebima (2009: 20) Model Reading Questioning Answering (RQA) merupakan: "Pembelajar ditugasi membaca materi pembelajaran tertentu, atas dasar pemahaman terhadap bacaan itu, para pembelajar diminta membuat pertanyaan secara tertulis dan menjawab sendiri". Subtansial yang ditanyakan adalah yang penting atau sangat penting terkait dengan materi bacaan, sedangkan jumlah pertanyaan disesuaikan dengan keadaan (dapat berkisar antara 3-4 nomor).Adapun penggunaan metodekonvensional memudahkan guru dalam menerapkan materi pelajaran.

Aktivitas siswa selama kegiatan berlangsung diobservasi oleh empat rekan mahasiswa pada kelas eksperimen dengan menggunakan model Reading Questioning Answering (RQA) selama dua kali pertemuan.

Berdasarkan hasil observasi yang telah dilakukan pada pertemuan pertama dan kedua menunjukkan bahwa siswa memperhatikan penjelasan guru dengan baik.Siswa sudah aktif belajar dikelas, hal ini terlihat dari aktivitas siswa yang mengajukan pertanyaan dan memberikan argumen berkaitan dengan materi yang disampaikan, begitu juga ketika presentasi dimulai siswa antusias menyimak dan saling memberikan saran dan masukan namun disisi lain guru merasa kualahan dalam mengelola kelas karena hal tersebut, tetapi tentusaja suasana kelas masih bisa terkodisi dengan baik. Hal ini menunjukan bahwa model Reading Questioning Answering (RQA) mampu menciptakan keakifan belajar sswa.

Aktivitas siswa dikelas kontrol pada pertemuan pertama menunjukan beberapa siswa kurang aktif dan ngan memberikan argumenya kurang mengajukan pertanyaan selama kegiatan belajar berlangsung sehingga kegiatan siswa berkuran dan lebih dominan kepada kegiatan guru hal ini dikerenakan guru mengajar dengan metode ceramah atau metode yang biasa digunakan oleh guru mengajar pada pertemuan sebelumnya. Pada pertemuan kedua terlihat siswa mulai aktif namun hanya sedikit dari mereka yang memberikan argumennya dan memberikan pertanyaan kepada guru. Walaupun demikian suasana kelas masih terlihat kondusif, baik pada pertemuan pertama maupun pertemuan kedua.

Analisis data pretest diberikan ntuk mengetahui kemampuan awal siswa pada materi sistem pernapsan manusia sebelum diberikan perlakan. Pretest diberikan pada kelas Eksperimen dan juga kelas Kontrol. Sementara itu, postest diberikan untuk mengetahui kemampuan berpikir kritis siswa pada materi sistem pernapasan manusia setelah diberi perlakuan dengan mengunakan model Reading Questionig Answering (RQA) pada kelas eksperimen dan pembelajaran dengan metode konvensional pada kelas kontrol. Data hasil pritest kelas eksperimen dan kelas kontrol dapat dilihat pada Tabel 2. 
Tabel 2. Nilai Kemampuan Berpikir Kritis Siswa

\begin{tabular}{lcccccl}
\hline \multirow{2}{*}{ Kelas } & \multicolumn{2}{c}{ Nilai } & Nilai Rata- & $\begin{array}{c}\text { Jumlah } \\
\text { Siswa }\end{array}$ & Katgori \\
\cline { 2 - 4 } & Terendah & Tertinggi & & rata & & \\
\hline Pretest Eksperimen & 20 & 55 & 38,78 & 33 & Kurang \\
\hline Pretest Kontrol & 20 & 55 & 39,68 & 32 & Kurang \\
\hline Posttest Eksperimen & 60 & 95 & 74,84 & 33 & Baik \\
\hline Posttest Kontrol & 50 & 85 & 65,62 & 32 & Cukup \\
\hline
\end{tabular}

Berdasarkan hasil data kemampan berpikir kritis siswa pada pretestkelas eksperimen diperoleh nilai tertinggi sebesar 55 dan nilai terendah 20 , nilai rata-rata sebesar 38,78 dengan jumlah siswa sebanyak 33 dengan kategori nilai "kurang". Adapun hasil Pretest kelas kontrol diproleh nilai tertinggi sebesar 55 dan nilai terendah 20, rata-rata nilai sebesar 39,68jumlah siswa sebanyak 32 siswadengan kategori nilai "kurang". Sementara itu hasil postestkemampuan berpikir kritis siswa pada kelas eksperimen diperoleh nilai tertinggi sebesar 95 dan nilai terendah sebesar 60 , rata-rata nilai sebesar 74,84 dengan kategori nilai "baik".

Adapun hasil postest kelas kontrol diperoleh nilai tertinggi sebesar 85 dan nilai terendah sebesar 50 , nilai rata-rata sebesar 65,62 dengan kategori nilai "cukup".Analisis uji normalitas diperoleh dari hasil pretest dan posttest siswa kelas VIII B sebagai kelas eksperimen dan hasil pretest dan posttest siswa kelas VIII C sebagai kelas kontrol. Dilihat dari hasil analisis indikator kemampuan berpikir kritis menunjukan hasil yang bervariasi dari masing-masing indikator. Hasil analisis indikator kemampuan berpikir kritis selengkapnya dapat dilihat pada Lampiran B-5, untuk rekapitulasi data hasil tes indikator kemampuan berpikir kritis secara umum dapat dilihat pada Tabel 3.

Tabel 3. Nilai Indikator Kemampuan Berpikir Kritis Siswa

\begin{tabular}{clcccc}
\hline \multirow{2}{*}{ No } & \multirow{2}{*}{$\begin{array}{c}\text { Indikator Berpikir } \\
\text { Kritis }\end{array}$} & \multicolumn{2}{c}{ Kelas Eksperimen } & \multicolumn{2}{c}{ Kelas Kontrol } \\
\cline { 3 - 6 } & Pretest & Posttest & Pretest & Posttest \\
\hline 1 & Merumuskan masalah & 45,45 & 78,78 & 50,00 & 81,25 \\
\hline 2 & Memberikan argumen & 50,00 & 92,42 & 37,50 & 82,81 \\
\hline 3 & Melakukan deduksi & 28,78 & 50,00 & 20,31 & 26,56 \\
\hline 4 & Melakukan induksi & 40,90 & 75,75 & 37,50 & 64,06 \\
\hline 5 & Melakukan evaluasi & 39,39 & 78,78 & 37,50 & 71,87 \\
\hline \multirow{2}{*}{6} & $\begin{array}{l}\text { Memutuskan dan } \\
\text { melaksanakan }\end{array}$ & 51,51 & 96,96 & 68,75 & 93,75 \\
\hline
\end{tabular}

Kemampuan berpikir kritis siswa kelas eksperimen dan kontrol, jika dilihat dari masingmasing indikator juga menunjukan perbedaan. Nilai tertinggi indikator berpikir kritis kelas eksperimen pada hasil posttestterdapat pada indikator memutuskan dan melaksanakan dengan nilai sebesar 96,96dan nilai pretest juga terdapat pada indikator memutuskan dan melaksanakan dengan nilai 51,51 .

Sedangkan di kelas kontrol nilai tertinggi hasil posttest juga terdapat pada indikator memutuskan dan melaksanakan dengn nilai sebesar 93,75 dan nilai pretest juga terdapat pada indikator memtuskan dan melaksanakan dengan nilai sebesar 68,75 . Adapun hasil uji normalitas dapat dilihat pada Tabel 4.

Analisis uji homogenitas data pretest dan posttest pada kelas eksperimen dan kontrol menggunakan uji $F$ dengan kriteria pengambilan keputusan jika jika $F_{\text {hitung }} \leq F_{\text {tabeiberarti data }}$ homogen, dan sebaliknya jika $F_{\text {hitung }}>F_{\text {tabel }}$ berartidata tidak homogen. Hasil uji homogenitaskelas eksperimen dan kelas kontrol dapat dilihat pada Tabel 5. 
Tabel 4. Hasil Uji Normalitas Kelas Eksperimen dan Kelas Kontrol

\begin{tabular}{clcccccc} 
No & Data yang dikaji & $\overline{\boldsymbol{X}}$ & SD & $\mathbf{X}^{2}$ Hitung & $\mathbf{X}^{2}$ Tabel & $\mathbf{A}$ & Ket. \\
\hline 1 & PretestEksperimen & 38,78 & 9,76 & 6,95 & 7,815 & 0,05 & Normal \\
\hline 2 & Pretest Kontrol & 39,68 & 8,51 & 4,73 & 7,815 & 0,05 & Normal \\
\hline 3 & PosttestEksperimen & 74,84 & 8,88 & 6,43 & 7,815 & 0,05 & Normal \\
\hline 4 & Posttestkontrol & 65,62 & 9,13 & 5,38 & 7,815 & 0,05 & Normal \\
\hline
\end{tabular}

Tabel 5. Hasil Uji Homogenitas Kelas Eksperimen dan Kelas Kontrol

\begin{tabular}{|c|c|c|c|c|c|}
\hline No & Data Yang Diuji & $\mathbf{S}^{2}$ & $F_{\text {hitung }}$ & $F_{\text {tabel }}$ & Keterangan \\
\hline 1 & Pretest Eksperimen & 95,35 & \multirow{2}{*}{1,31} & \multirow[b]{2}{*}{1,83} & \multirow{2}{*}{ Homogen } \\
\hline 2 & Pretest Kontrol & 72,47 & & & \\
\hline 3 & Posttest Eksperimen & 78,91 & \multirow{2}{*}{1,05} & \multirow{2}{*}{1,81} & \multirow{2}{*}{ Homogen } \\
\hline 4 & Posttest Kontrol & 83,46 & & & \\
\hline
\end{tabular}

Uji hipotesis dalam penelitian ini menggunakan uji paramerik dengan uji Z- dua sampel. Adapun hasil data Pretest untuk kelas eksperimen dan kelas kontrol dapat dilihat pada Tabel 6.

Tabel 6. Hasil Uji Hipotesis dengan Uji Z-dua Sampel untuk Pretest

\begin{tabular}{|c|c|c|c|c|c|}
\hline Kelas & $\mathbf{N}$ & Pretest & $Z_{\text {hitung }}$ & $\mathbf{Z}_{\text {tabel }}$ & Keterangan \\
\hline Eksperimen & & & \multirow{4}{*}{$-0,55$} & \multirow{4}{*}{1,96} & \multirow{4}{*}{$\begin{array}{c}\text { Tidak terdapat perbedaan yang } \\
\text { signifikan kemampuan berpikir } \\
\text { kritis antara siswa kelas } \\
\text { eksperimen dan siswa kelas } \\
\text { kontrol }\end{array}$} \\
\hline & 33 & 38,78 & & & \\
\hline & & & & & \\
\hline Kontrol & 32 & 39,68 & & & \\
\hline
\end{tabular}

Sedangkan hasil Posttest data kelas eksperimen dan kontrol secara umum dapat dilihat pada Tabel 7.

Tabel 7. Hasil Uji Hipotesis dengan Uji Z-dua Sampel untuk Posttest

\begin{tabular}{cccccc}
\hline Kelas & $\mathbf{N}$ & $\begin{array}{c}\text { Rerata } \\
\text { Posttest }\end{array}$ & $\mathbf{Z}_{\text {hitung }}$ & $\begin{array}{c}\mathbf{Z}_{\text {tabel }} \\
(\alpha=5 \%)\end{array}$ & Keterangan \\
\hline Eksperimen & 33 & 74,84 & 5,76 & 1,96 & $\begin{array}{c}\text { Terdapat perbedaan yang } \\
\text { signifikan kemampuan berpikir } \\
\text { kritis antara siswa kelas } \\
\text { eksperimen dan siswa kelas } \\
\text { Kontrol }\end{array}$ \\
\hline
\end{tabular}

Berdasarkan uji hipotesis data pretestkelas eksperimen dan kelas kontrol diketahui nilai $Z_{\text {hitung }}<Z_{\text {tabelyaitu }}-0,55<1,96$ maka $\mathrm{Ha}$ ditolak dan $\mathrm{H}_{0}$ diterima, yang artinya tidak terdapat perbedaan yang signifikan kemampuan berpikir kritis siswa antara kelas eksperimen dan kelas kontrol. Sedangkan hasil posttest nilai $Z_{\text {hitung }}>Z_{\text {tabelyaitu }}$ 5,76>1,96 maka $\mathrm{H}_{0}$ ditolak dan $\mathrm{Ha}$ diterima, dapat disimpulakan bahwa terdapat perbedaan yang signifikan kemampuan berpikirkritissiswa dikels Eksperimendenganmenggunakan model Reading Questioning Answering(RQA) dan kelaskontrol menggunakan metode konvension. 
Hasil angket respon siswa terhadap model Reading Questioning Answering (RQA) dari 33 responden yang diberi angket, dapat diketahui bahwa perolehan total rata-rata jawaban sebesar $1711 \%$ dengan rata-rata prsentase $85,55 \%$, dengan kriteria "Baik Sekali". Maka dapat disimpulkan bahwa tanggapan siswa terhadap model pembelajaranReading Questioning Answering (RQA)sangat baik.

Hasil tanggapan ini dapat memberikan gambaran bahwa modelReading Questioning Answering (RQA)dapat menjadi salah satu pilihan alternatif yang sangat baik untuk diterapkan pada proses pembelajaran di sekolah dalam mengatasi siswa yang bersifat pasif dan malas belajar. Mulyadi (2013) "Menunjukan bahwa respon mahasiswa terhadap penerapan Reading Questioning Answering (RQA) pada perkuliahan botani tumbuhan rendah dinyatakan tinggi. Banyak hal yang positif didapatkan mahasiswa terutama dalam hal mengembangkan kemampuan berpikir, meningkatkan motivasi, serta menciptakan suasana belajar yang kondunsif.

Penerapan model Reading Questioning Answering (RQA)juga dapat meningkatkan rasa percaya diri karena siswa dilatih untuk aktif dalam mengemukakan argumen mereka ketika presentasi dilaksanakan. Hal ini dikatakan oleh Hasanuddin (2012) "Bahwa model Reading Questioning Answering (RQA) "Merupakan hal baru bagi mereka $(100 \%)$ menyadarkan mereka akan pentingnya kemandirian dalam belajar (100\%), telah mampu mengatur cara belajar serta mampu mengevaluasi pembelajaran yang mereka lakukan".

Hal ini dikarenakan penerapan model Reading Questioning Answering (RQA)membuat siswa menyukai suasana kelas dan tidak mudah bosan terhadap proses pembelajaran yang sedang berlangsung.

\section{SIMPULAN}

Berdasarkan hasil dan pembahasan, maka kesimpulan dalam penelitian ini sebagai berikut: (1) Kemampuan berpikir kritis siswa di kelas eksperimen diperoleh nilai rata-rata sebesar38,78 dengan kategori "kurang" dan sesudah penerapan modelReading Questioning Answering (RQA)diperoleh nilai rata-rata 74,84 dengan kategori "baik". Sedangkan kemampuan berpikir kritis siswa di kelas kontrol diperoleh nilai rata-rata sebesar 39,68 dengan kategori "kurang" dan sesudah penerapan metode konvensional diperoleh nilai rata-rata sebesar 65,62 dengan kategori "baik"; (2) Pada hasil pretestdiketahui bahwa nilai $Z_{\text {hitung }}<Z_{\text {tabel }}$ yaitu $-715<1,96$ maka Ho diterima yang artinya tidakterdapat perbedaan yang signifikan kemampuan berpikir kritis siswa antara kelas eksperimen dengan kelas kontrol pada materi sistem pernapasanmanusia. Adapun pada hasil posttest diketahui bahwa nilai $Z_{\text {hitung }}>Z_{\text {tabel }}$ yaitu 5,76 $>$ 1,96 maka Ha diterima yang artinya terdapat perbedaan yang signifikan kemampuan berpikir kritis siswa antara kelas eksperimen dengan kelas kontrol; (3) Respon siswa terhadap penerapan model Reading Questioning Answering (RQA) pada pokok bahasan sistem pernapasan manusia di kelas VIII SMP Negeri 02 Sintangdengan kategori "sangat baik" yaitu dengan perolehan ratarata presentase sebesar $85,55 \%$ berkriteria"baik sekali" terhadap penerapan model Reading Questioning Answering (RQA).

\section{REFERENSI}

Bahtiar, (2013). Potensi Pembelajaran Yang Memadukan Strategi Think Pairs Share (TPS)Dan Reading Questioning Answering (RQA) Untuk Meningkatkan Sikap Sosial Dan Penguasaan Konsep Biologi Siswa Sma Multietnis Di Ternate. Jurnal. Seminar Nasional X Pendidikan Biologi FKIP UNS.

Bustami, Y. (2017). Pengaruh Strategi Pembelajaran JiRQA Terhadap Kemampuan Kognitif, Keterampilan Berpikir Kritis, dan Sikap Sosial Mahasiswa Multietnis Pada 
Perkuliahan Zoologi di STKIP Persada Khatulistiwa Sintang. Disertasi tidak diterbitkan. Malang: Pascasarjana Universitas Negeri Malang

Bustami, Y.,\& Corebima, A.D. (2017). The Effect of JiRQA Learning Strategy on Critical Thinking Skills of Multiethnic Students in Higher Education, Indonesia. International Journal of Humanities Social Sciences and Education (IJHSSE), 4(3), 13-22.

Corebima, A. D. (2009). Pengalaman Berupaya Menjadi Guru Profesional. Pidato pengukuhan Guru Besar pada FMIPAUM. Disampaikan pada SidangTerbuka Senat UM, tanggal 30 Juli.

Corebima, A. D. (2010). Berdayakan Keterampilan Berpikir Selama Pembelajaran Sains Demi MasaDepan Kita. Makalah. Disampaikan pada Seminar Nasional Sains, yang diselenggarakan di Universitas Negeri Surabaya, 16 Januari 2010

Fisher, A. (2009).Berpikir Kritis Sebuah Pengantar. Jakarta Erlangga.

Mulyadi. (2013). Pengaruh Model Pembelajaran Reading Questioning Answering (RQA) Pada Perkuliahan Botani Tumbuhan Rendah Terhadap Kemampuan Berpikir dan Hasil Belajar Kognitif. Skipsi tidak diterbitkan. Banda aceh: Universitas Siah kuala.

Sugiyono. (2011). Metode Penelitian Kuantitatif Kualitatif dan R\&D. Bandung: Alfabeta.

Sugiyono. (2013). Metode Penelitian Kuantitatif Kualitatif dan R\&D. Bandung: Alfabeta.

Tariga. (2015). Membaca Sebagai Suatu Keterampilan Berbahasa. Bandung: CV Angkas. 